\title{
Influence of variety, organic and mineral fertilization on the qualitative and quantitative characteristics of cucumbers crop (Cucumis sativus L.)
}

\author{
${ }^{1}$ Athari J. Mohammed, ${ }^{2}$ Razzaq A. Saqar ${ }^{3}$ Muaid S. Ali \\ ${ }^{1,2,3}$ University of Thi-Qar, College of Agriculture and Marshlands, Department of Horticulture and Landscape \\ 1Email:muaid-ali@utq.edu.iq \\ ${ }^{2}$ Email:razak-abd@utq.edu.iq \\ 3Email:kkosaa12.post.am@utq.edu.iq
}

\begin{abstract}
:
The experiment was carried out at the Agricultural Research Station of the College of Agriculture and the Marshlands / University of Thi-Qar, located in Al- Mustufawia for the agricultural season (2019-2020). The study was the effect of cultivar and organic and mineral fertilization on the qualitative and quantitative characteristics of cucumber crops grown in greenhouses, and applied according to the factorial experiments inside the split plots, using the complete randomized sectors with three replications. The factors of research were: two cultivars (Datis and Sakata) occupied the main plots, three levels of organic fertilization occupied the secondary plots which included control treatment $\mathrm{O}_{1}$, cow manure $\mathrm{O}_{2}\left(2.457\right.$ tons of greenhouse $\left.\mathrm{e}^{-1}\right)$ and poultry manure $\mathrm{O}_{3}\left(3.713\right.$ tons of greenhouse $\left.{ }^{-1}\right)$ and the third factor was four levels of mineral fertilization (NPK) including control treatment $\mathrm{M}_{1}, \mathrm{M}_{2}\left(2.250 \mathrm{~kg}\right.$. dunam $\left.{ }^{-1}\right), \mathrm{M}_{3}\left(3.350 \mathrm{~kg}\right.$. dunam $\left.{ }^{-1}\right)$, and $\mathrm{M}_{4}$ $\left(4.450 \mathrm{~kg}\right.$. dunam $\left.{ }^{-1}\right)$ which occupied the sub-plots. The results showed that Datis cultivar significantly outperformed Sakata cultivar in yield per plant, total yield, leaf content of nitrogen and phosphorus, and fruit content of carbohydrates, reaching (1.402 kg. plant $^{-1}, 24.24$ tons .greenhoues $\left.{ }^{-1}, 2.2517 \%, 0.4069 \%, 1.2876 \%\right)$ respectively. On the other hand, the treatment of organic fertilizer $\mathrm{O}_{3}$ recorded a significant effect in the following crop traits such as leaf area, total yield, leaf content of nitrogen and phosphorus, and fruit content of carbohydrate, reaching $\left(178.0 \mathrm{~cm}^{2}, 24.36\right.$ tons. greenhouse ${ }^{-1}$, $2.5017 \%, 0.4608 \%, 1.3561 \%)$. Respectively compared to other treatments, total yield, leaf content of nitrogen and phosphorus, reaching $\left(180.1 \mathrm{~cm}^{2}, 25.88 \mathrm{t}\right.$. greenhoues ${ }^{-1}$, and $2.3478 \%$, and $\left.0.4561 \%\right)$ to other treatments. The treatment $\mathrm{M}_{2}$ significantly outperformed in yield per plant (1.682) kg. plant ${ }^{-1}$ and treatment $\mathrm{M}_{3}$ significantly exceeded the fruit's carbohydrate content, reaching $(1.2930 \%)$. All the combinations among this study's treatments were compared to meet their significant effecting on all traits.
\end{abstract}

Keyword: Organic fertilization, Mineral fertilization, cucumber, Cucumis sativus L.

\section{INTRODUCTION}

Cucumber (Cucumis sativus L.) is one of the major vegetable crops in the world and Iraq. It belongs to the Cucurbitaceae family, which is a monoculture plant that is characterized by being climbing or creeping. Cucumber is one of the main vegetable crops in the hot region's market. However, its fruits are of less nutritional importance compared to other 
vegetable fruits. It is still a good source of vitamins B5, B6, K and C. and A also elements such as potassium, magnesium, phosphorous, copper and manganese; also it contains dietary fiber(Vimala et al., 1999). Its fruits also contain ascorbic acid and caffeic acid, both of which help relieve irritation and skin health. Fruits of Cucumber have an important role in relieving nervous disorders, purifying the body from toxins, headache reliever, a thirst remover, and a diuretic(Duke, 1997). Cucumber is one of crops that need high nutritional requirements. Its field performance is poor in the event of a lack of nutrients in the soil, which leads to low yield, deformation of fruits and bitterness of its taste, for maintaining an acceptable level of its production, should be raised soil's nutritional status by preserving its fertility to meet need for crop. One of its methods is use of organic or inorganic fertilizers, as their application intends to increase agricultural production by not less than $50 \%$ provided that other growth factors are ideally available(Ali, 2007). This led to using of chemical fertilization to solve this problem. However, most fertilizers added to the soil, especially nitrogenous ones, are exposed to many factors that lead to poor performance and lack of efficiency, such as volatilization, stabilization, and washing below the root zone, which pollute the groundwater. These fertilizers contain nitrogen, phosphorous, potassium and micro-nutrients for healthy growth of plants.

Organic matter positively affects the physical and chemical properties of soil and fertility, such as soil acidity, reducing calcium carbonate, supplying plants with the necessary nutrients, including nitrogen, potassium and phosphorous, in addition to its role in holding water much more significant than its weight due to its high surface area, improving soil composition and increasing capillary pores, which helps soils increasing its ability to hold water. It is necessary to devise more productive varieties while supplying the plant with its nutrients, whether by adding mineral fertilizers and organic extracts that have a fundamental role in increasing production. Mineral fertilizers provide the major and main elements of $\mathrm{N}, \mathrm{P}$, and $\mathrm{K}$ necessary for growth and production, which is reflected in this Increase yield and improve its quality.

The study aimed to determine the appropriate variety for Thi-Qar governorate conditions when protected cultivation inside greenhouses. Also, producing high yield of cucumber crop was studied the possibility of producing the cucumber crop within the use of organic and mineral fertilizers and determining the quantity and quality of the appropriate organic and mineral fertilizers to achieve the best yield in quantity and quality.

\section{MATERIALS AND METHODS}

\section{A. Field of study}

The study was conducted in Thi-Qar Governorate - Nasiriya city Al Mustufawia region, for the 2019-2020 agricultural seasons in an unheated greenhouse of the college of agriculture and marshlands / University of Thi-Qar in sandy mix soil for studying the effect of the cultivar and organic and mineral fertilization on the physical and chemical properties of cucumbers.

\section{B. Experimental design and treatments}

The experiment was carried out using a factorial experiment within the split-plot design using a randomized complete block design (RCBD) with three replicates. The experiment included 72 treatments, so the first factor was two Cucumber varieties (Datis and Sakata), a symbol of $V_{1}$ and $V_{2}$, where it occupied the main plots. The second factor included three 
organic fertiliser levels (comparison, beef manure, poultry manure) with the levels $(0,3.713,2.457)$ tons-greenhouse ${ }^{-1}$, which is symbolized as $\left(\mathrm{O}_{1}, \mathrm{O}_{2}, \mathrm{O}_{3}\right)$ respectively. The third one has four mineral fertiliser levels ( NPK) by average $(0,2.250,3.350,4.450) \mathrm{kg}$. $\mathrm{du}^{-1}$ which are denoted by the symbols $\left(\mathrm{M}_{1}, \mathrm{M}_{2}, \mathrm{M}_{3}, \mathrm{M}_{4}\right)$ respectively. Both the second and third factors were occupied in sub-plot as factorial factors. Data were analyzed according to GenStat (2011), and the means of treatments were compared using the least significant difference test (L. S. D) under a probability level ( $p \geq 0.05)$ (Sahuki and Waheeb, 1990).

\section{RESULTS}

\section{A. Leaf area $(\mathrm{cm} 2)$}

The results in a table (1) showed that the treatment of organic fertilizer O3 was significantly superior in giving the highest rate of $(178.0 \mathrm{~cm} 2)$ in Leaf area compared with other treatments $\mathrm{O} 1$ and $\mathrm{O} 2$, which gave the lowest rate of leaf area (158.0 and $159.1 \mathrm{~cm} 2)$ respectively. Treatment M4 showed significant superiority in providing the highest average of leaf area $(180.1 \mathrm{~cm} 2)$, which did not differ significantly with M2 which reached $(177.3 \mathrm{~cm} 2)$ of leaf area, while treatment M1 and M3 gave the lowest average of this trait, was (160.2 and 142.6) $\mathrm{cm} 2$, respectively. The interaction between the two types of fertilizers had a significant effect on this characteristic, as the combination of $(\mathrm{O} 3 \times \mathrm{M} 2)$ gave the highest average was $203.3 \mathrm{~cm} 2$ compared to the combination $(\mathrm{O} 1 \times \mathrm{M} 1)$ and $(\mathrm{O} 2 \times \mathrm{M} 2)$, which gave lowest average $140.0 \mathrm{~cm} 2$ and 135.1 $\mathrm{cm} 2$ respectively.

TABLE (1): EFFECT OF CULTIVARS, ORGANIC AND MINERAL FERTILIZATION AND THEIR INTERACTIONS ON LEAF AREA OF CUCUMBERS (CM²)

\begin{tabular}{|c|c|c|c|c|c|c|}
\hline \multirow[b]{2}{*}{ Variety (V) } & \multirow{2}{*}{$\begin{array}{c}\text { Organic } \\
\text { fertilization } \\
\text { (O) }\end{array}$} & \multicolumn{4}{|c|}{ Mineral fertilization (M) } & \multirow[b]{2}{*}{$\mathbf{V} * \mathbf{O}$} \\
\hline & & $\mathbf{M}_{1}$ & $\mathbf{M}_{2}$ & $\mathbf{M}_{3}$ & $\mathbf{M}_{4}$ & \\
\hline & $\mathrm{O}_{1}$ & 151.3 & 205.7 & 153.2 & 177.3 & 171.9 \\
\hline & $\mathrm{O}_{2}$ & 185.5 & 139.4 & 166.5 & 192.3 & 170.9 \\
\hline \multirow[t]{3}{*}{$\overline{V_{1}}$} & $\mathrm{O}_{3}$ & 187.1 & 220.3 & 142.4 & 199.9 & 187.4 \\
\hline & $\mathrm{O}_{1}$ & 128.7 & 181.4 & 137.0 & 129.7 & 144.2 \\
\hline & $\mathrm{O}_{2}$ & 134.7 & 130.8 & 134.4 & 189.4 & 147.2 \\
\hline $\mathbf{V}_{2}$ & $\overline{\mathrm{O}_{3}}$ & 173.9 & 186.4 & 122.5 & 191.8 & 168.7 \\
\hline \multirow[t]{3}{*}{ L.S.D 0.05} & \multicolumn{5}{|c|}{$\mathbf{V} \times \mathbf{O} \times \mathbf{M}=\mathbf{N} . \mathrm{S}$} & $\mathrm{V} * \mathrm{O}=\mathrm{N} . \mathrm{S}$ \\
\hline & & & & & & $\operatorname{Mean}(\mathrm{V})$ \\
\hline & $\overline{V_{1}}$ & 174.6 & 188.5 & 154.0 & 189.8 & 176.7 \\
\hline$\overline{\mathbf{V} \times \mathbf{M}}$ & $\overline{\mathrm{V}_{2}}$ & 145.8 & 166.2 & 131.2 & 170.3 & 153.4 \\
\hline \multirow[t]{2}{*}{ L.S.D 0.05} & \multicolumn{5}{|c|}{$\mathbf{V} \times \mathbf{M}=\mathrm{N} . \mathrm{S}$} & $\mathbf{V}=\mathrm{N} . \mathrm{S}$ \\
\hline & & & & & & Mean (O) \\
\hline $\mathbf{O} \times \mathbf{M}$ & $\mathrm{O}_{1}$ & 140.0 & 193.6 & 145.1 & 153.5 & 158.0 \\
\hline
\end{tabular}


University of Thi-Qar Journal of agricultural research

ISSN Onlin:2708-9347, ISSN Print: 2708-9339 Volume 10, Issue 1 (2021) PP 1-12

https://jam.utq.edu.iq/index.php/main $\quad$ https://doi.org/10.54174/UTJagr.Vo10.N1./01

\begin{tabular}{|c|c|l|l|l|l|l|}
\hline & $\mathrm{O}_{2}$ & 160.1 & 135.1 & 150.3 & 190.8 & 159.1 \\
\hline \hline $\mathrm{O}_{3}$ & 180.5 & 203.3 & 132.5 & 195.9 & 178.0 \\
\hline \multicolumn{2}{|c|}{ Mean (M) } & 160.2 & 177.3 & 142.6 & 180.1 & \\
\hline L.S.D \\
$\mathbf{0 . 0 5}$ & $\mathbf{O} \times \mathbf{M}=20.97$ & $\mathbf{M}=12.11$ & $\mathbf{O}=10.48$ \\
\hline
\end{tabular}

Varieties $\left(\mathrm{V}_{1}=\right.$ Datis, $\mathrm{V}_{2}=$ Sakata $)$; Organic fertilizer $\left(\mathrm{O}_{1}=\right.$ comparison, $\mathrm{O}_{2}=$ beef manure, $\mathrm{O}_{3}=$ poultry manure $)$; Mineral fertilizer (NPK) $\left(\mathrm{M}_{1}=0, \mathrm{M}_{2}=2.250, \mathrm{M}_{3}=3.350, \mathrm{M}_{4}=4.450\right) \mathrm{kg}$. dunam ${ }^{-1}$.

\section{B. Total yield (kg. greenhouse $\left.{ }^{-1}\right)$}

The results of Table (2) showed that cultivar $\mathrm{V}_{1}$ was significantly superior compared to variety $\mathrm{V}_{2}$ and recorded the highest average of total yield (24.24) $\mathrm{kg}$. greenhouse ${ }^{-1}$ compare to 19.84$) \mathrm{kg}$ of the second cultivar, respectively. The results indicated that organic fertilizer $\mathrm{O}_{3}$ was significantly superior by giving the highest average of total yield (24.36 kg) $\mathrm{kg}$. greenhouse ${ }^{-1}$, which did not differ significantly from treatment $\mathrm{O}_{2}$, showed an average of (22.77) $\mathrm{kg}$. greenhouse ${ }^{-1}$ compared with treatment $\mathrm{O}_{1}$, which gave the lowest average of (18.99) kg. greenhouse-1. Treatments $\mathrm{M}_{2}$ and $\mathrm{M}_{4}$ significantly affected the total yield and recorded the highest average of total yield $(25.88 \mathrm{~kg})$, while the treatments $\mathrm{M} 1$ and $\mathrm{M}_{3}$ gave the lowest average (17.48 and $18.92 \mathrm{~kg}$ ) respectively.

The combination of $\left(\mathrm{V}_{1} \times \mathrm{O}_{3}\right)$ recorded the highest average for this trait $27.72 \mathrm{~kg}$, while the combination $\left(\mathrm{V}_{2} \times \mathrm{O}_{1}\right)$ gave the lowest rate of $18.36 \mathrm{~kg}$. The combination $\left(\mathrm{V}_{1} \times \mathrm{M}_{4}\right)$ achieved the highest average $30.16 \mathrm{~kg}$, while treatment $\left(\mathrm{V}_{2} \times \mathrm{M}_{1}\right)$ showed the lowest yield of $17.20 \mathrm{~kg}$. Also, the interaction between two types of fertilizers had a significant effect on this aspect. A combination $\left(\mathrm{O}_{3} \times \mathrm{M}_{2}\right)$ gave the highest average $38.40 \mathrm{~kg}$ compared to $\left(\mathrm{O}_{1} \times \mathrm{M}_{1}\right)$, giving the lowest average of total yield $14.41 \mathrm{~kg}$. The triple among the factors achieved a significant effect in this trait the combination $\left(\mathrm{V}_{1} \times \mathrm{O}_{3} \times \mathrm{M}_{2}\right)$

gave the highest average $46.08 \mathrm{~kg}$, while the combination $\left(\mathrm{V}_{2} \times \mathrm{O}_{1} \times \mathrm{M}_{1}\right)$ gave the lowest $16.08 \mathrm{~kg}$. This may be interpreted based on the influence of individual factors.

TABLE(2): EFFECT OF CULTIVAR, ORGANIC AND MINERAL FERTILIZATION AND THEIR INTERACTIONS ON TOTAL YIELD (KG. GREENHOUSE ${ }^{-1}$ )

\begin{tabular}{|c|c|c|c|c|c|c|}
\hline \multirow[b]{2}{*}{ Variety (V) } & \multirow{2}{*}{$\begin{array}{c}\text { Organic } \\
\text { fertilization } \\
\text { (O) }\end{array}$} & \multicolumn{4}{|c|}{ Mineral fertilization (M) } & \multirow[b]{2}{*}{$\mathbf{V * O}$} \\
\hline & & $\mathbf{M}_{1}$ & $\mathbf{M}_{2}$ & $\mathbf{M}_{3}$ & $\mathbf{M}_{4}$ & \\
\hline & $\mathrm{O}_{1}$ & 12.75 & 25.92 & 17.76 & 22.08 & 19.63 \\
\hline \multirow[t]{3}{*}{$\mathbf{V}_{1}$} & $\mathrm{O}_{2}$ & 22.56 & 15.36 & 25.20 & 38.40 & 25.38 \\
\hline & $\mathrm{O}_{3}$ & 18.00 & 46.08 & 16.80 & 30.00 & 27.72 \\
\hline & $\mathrm{O}_{1}$ & 16.08 & 21.12 & 16.80 & 19.44 & 18.36 \\
\hline \multirow[t]{2}{*}{$\mathbf{V}_{2}$} & $\mathrm{O}_{2}$ & 18.72 & 16.08 & 21.36 & 24.48 & 20.16 \\
\hline & $\mathrm{O}_{3}$ & 16.80 & 30.72 & 15.60 & 20.88 & 21.00 \\
\hline L.S.D 0.05 & \multicolumn{5}{|c|}{$\mathbf{V} \times \mathbf{O} \times \mathbf{M}=6.748$} & $\mathbf{V} * \mathbf{O}=3.345$ \\
\hline \multirow{2}{*}{$\mathbf{V} \times \mathbf{M}$} & & & & & & Mean (V) \\
\hline & $\mathrm{V}_{1}$ & 17.77 & 29.12 & 19.92 & 30.16 & 24.24 \\
\hline
\end{tabular}


University of Thi-Qar Journal of agricultural research

ISSN Onlin:2708-9347, ISSN Print: 2708-9339 Volume 10, Issue 1 (2021) PP 1-12

https://jam.utq.edu.iq/index.php/main $\quad$ https://doi.org/10.54174/UTJagr.Vo10.N1./01

\begin{tabular}{|c|c|c|c|c|c|c|}
\hline & $\mathrm{V}_{2}$ & 17.20 & 22.64 & 17.92 & 21.60 & 19.84 \\
\hline \hline L.S.D & \multicolumn{5}{|c|}{$\mathbf{V} \times \mathbf{M}=3.849$} & $\mathbf{V}=3.536$ \\
\hline \hline $\mathbf{O} \times \mathbf{M}$ & $\mathrm{O}_{1}$ & 14.41 & 23.52 & 17.28 & 20.76 & Mean (O) \\
\hline
\end{tabular}

\begin{tabular}{|c|c|l|l|l|l|c|}
\hline & $\mathrm{O}_{2}$ & 20.64 & 15.72 & 23.28 & 31.44 & 22.77 \\
\hline \hline & $\mathrm{O}_{3}$ & 17.40 & 38.40 & 16.20 & 25.44 & 24.36 \\
\hline \multicolumn{2}{|c|}{ Mean (M) } & 17.48 & 25.88 & 18.92 & 25.88 & \\
\hline L.S.D & \multicolumn{3}{|c|}{$\mathbf{M}=2.793$} \\
\hline
\end{tabular}

Varieties $\left(\mathrm{V}_{1}=\right.$ Datis, $\mathrm{V}_{2}=$ Sakata); Organic fertilizer $\left(\mathrm{O}_{1}=\right.$ comparison, $\mathrm{O}_{2}=$ beef manure, $\mathrm{O}_{3}=$ poultry manure); Mineral fertilizer (NPK) $\left(\mathrm{M}_{1}=0, \mathrm{M}_{2}=2.250, \mathrm{M}_{3}=3.350, \mathrm{M}_{4}=4.450\right) \mathrm{kg}$. dunam ${ }^{-1}$.

\section{The percentage of nitrogen in the leaves $(\%)$}

The results (Table. 3) showed that cultivar $V_{1}$ was significantly superior compared to cultivar $V_{2}$ in the percentage of leaves' nitrogen content (2.2517 and 2.1150) \% for each, respectively. The results also indicated that treatment of organic fertilizer $\mathrm{O}_{3}$ was significantly superior in giving the highest average of this trait $(2.5017 \%)$ but did not differ significantly with $\mathrm{O} 2$ treatment that recorded $(2.2696 \%)$. The treatment $\mathrm{O} 1$ recorded the lowest average $(1.7787 \%)$.

The effect of mineral fertilizer appeared the significant impact on this trait; thus the treatments $\mathrm{M}_{4}, \mathrm{M}_{3}$, and $\mathrm{M}_{2}$ recorded the highest average percentage of nitrogen $(2.348,2.220$, and $2.140 \%)$ respectively compared to control treatment that recorded the lowest average $(2.025 \%)$.

The binary interaction between cultivars and the organic fertilization showed a significant effect, the combination $\left(\mathrm{V}_{1} \times\right.$ $\mathrm{O}_{3}$ ) gave the highest average of this trait, which reached $2.5383 \%$. In comparison, the combination $\left(\mathrm{V}_{2} \times \mathrm{O}_{1}\right)$ showed the lowest was $1.6592 \%$. The combination $\left(\mathrm{V}_{1} \times \mathrm{M}_{4}\right)$ and $\left(\mathrm{V}_{2} \times \mathrm{M}_{4}\right)$ significantly exceeded the other combination and recorded the highest average for this trait, reaching $2.3878 \%$ and $2.3078 \%$, respectively, while the combination $\left(\mathrm{V}_{2} \times \mathrm{M}_{1}\right)$ gave the lowest was $1.9367 \%$. The combination $\left(\mathrm{O}_{3} \times \mathrm{M}_{2}\right)$ also gave the highest average, reaching $2.6383 \%$, compared to $\left(\mathrm{O}_{1} \times \mathrm{M}_{1}\right)$ which gave the lowest $1.6167 \%$. The triple interaction treatment among varieties, organic and mineral fertilization achieved a significant effect in this trait. Thus, combination $\left(\mathrm{V}_{1} \times \mathrm{O}_{3} \times \mathrm{M}_{2}\right)$ gave the highest average at $2.6600 \%$, while the combination $\left(\mathrm{V}_{2} \times \mathrm{O}_{1} \times \mathrm{M}_{1}\right)$ gave the lowest one was $1.6167 \%$.

TABLE(3): EFFECT OF CULTIVAR, ORGANIC AND MINERAL FERTILIZATION AND THEIR INTERACTIONS ON THE PERCENTAGE OF NITROGEN IN THE LEAVES (\%)

\begin{tabular}{|c|c|c|c|c|c|c|}
\hline & Organic & \multicolumn{3}{|c|}{ Mineral fertilization (M) } & \\
\hline \hline Variety (V) & $\begin{array}{c}\text { fertilization } \\
(\mathbf{O})\end{array}$ & $\mathbf{M}_{\mathbf{1}}$ & $\mathbf{M}_{\mathbf{2}}$ & $\mathbf{M}_{\mathbf{3}}$ & $\mathbf{M}_{\mathbf{4}}$ & $\mathbf{V} * \mathbf{O}$ \\
\hline \hline $\mathbf{V}_{\mathbf{1}}$ & $\mathrm{O}_{1}$ & 1.7967 & 1.8467 & 1.9000 & 2.0500 & 1.8983 \\
\hline
\end{tabular}


University of Thi-Qar Journal of agricultural research

ISSN Onlin:2708-9347, ISSN Print: 2708-9339 Volume 10, Issue 1 (2021) PP 1-12

https://jam.utq.edu.iq/index.php/main https://doi.org/10.54174/UTJagr.Vo10.N1./01

\begin{tabular}{|c|l|l|l|l|l|l|}
\hline & $\mathrm{O}_{2}$ & 2.1467 & 2.3133 & 2.3600 & 2.4533 & 2.3183 \\
\cline { 2 - 7 } & $\mathrm{O}_{3}$ & 2.3967 & 2.5267 & 2.5700 & 2.6600 & 2.5383 \\
\hline \multirow{2}{*}{$\mathbf{V}_{\mathbf{2}}$} & $\mathrm{O}_{1}$ & 1.4367 & 1.5200 & 1.7300 & 1.9500 & 1.6592 \\
\cline { 2 - 7 } & $\mathrm{O}_{2}$ & 2.0933 & 2.2000 & 2.2333 & 2.3567 & 2.2208 \\
\hline
\end{tabular}

\begin{tabular}{|c|c|c|c|c|c|c|}
\hline & $\mathrm{O}_{3}$ & 2.2800 & 2.4367 & 2.5267 & 2.6167 & 2.4650 \\
\hline L.S.D ${ }_{0.05}$ & \multicolumn{5}{|c|}{$\mathbf{V} \times \mathbf{O} \times \mathbf{M}=0.07305$} & $\mathbf{V} * \mathbf{O}=0.03172$ \\
\hline \multirow{3}{*}{$\mathbf{V} \times \mathbf{M}$} & & & & & & Mean (V) \\
\hline & $\mathrm{V}_{1}$ & 2.1133 & 2.2289 & 2.2767 & 2.3878 & 2.2517 \\
\hline & $\mathrm{V}_{2}$ & 1.9367 & 2.0522 & 2.1633 & 2.3078 & 2.1150 \\
\hline \multirow[t]{2}{*}{ L.S.D 0.05} & \multicolumn{5}{|c|}{$\mathbf{V} \times \mathbf{M}=0.03856$} & $\mathbf{V}=0.01449$ \\
\hline & & & & & & Mean (O) \\
\hline \multirow{3}{*}{$\mathbf{O} \times \mathbf{M}$} & $\mathrm{O}_{1}$ & 1.6167 & 1.6833 & 1.8150 & 2.000 & 1.7787 \\
\hline & $\mathrm{O}_{2}$ & 2.1200 & 2.2967 & 2.2967 & 2.4050 & 2.2696 \\
\hline & $\mathrm{O}_{3}$ & 2.3383 & 2.4817 & 2.2967 & 2.6383 & 2.5017 \\
\hline \multicolumn{2}{|c|}{ Mean (M) } & 2.0250 & 2.1406 & 2.2200 & 2.3478 & \\
\hline L.S.D 0.05 & $\mathbf{O} \times \mathbf{M}=0.05374$ & \multicolumn{4}{|c|}{$\mathbf{M}=0.03103$} & $\mathbf{O}=0.02687$ \\
\hline
\end{tabular}

Varieties $\left(\mathrm{V}_{1}=\right.$ Datis, $\mathrm{V}_{2}=$ Sakata); Organic fertilizer $\left(\mathrm{O}_{1}=\right.$ comparison, $\mathrm{O}_{2}=$ beef manure, $\mathrm{O}_{3}=$ poultry manure); Mineral fertilizer (NPK) $\left(\mathrm{M}_{1}=0, \mathrm{M}_{2}=2.250, \mathrm{M}_{3}=3.350, \mathrm{M}_{4}=4.450\right) \mathrm{kg}_{\text {. dunam }}{ }^{-1}$.

\section{Percentage of phosphorous in leaves (\%)}

The results indicated that cultivar $V_{1}$ was significantly superior to cultivar $V_{2}$ at average of $(0.4069$ and 0.3536$) \%$ respectively (Table, 4). The treatments of organic fertilizer $\mathrm{O}_{3}$ and $\mathrm{O}_{2}$ were significantly exceeding in giving the highest average $(0.4408 \%)$ respectively, compared to other treatments and $\mathrm{O} 1$ recorded the lowest average $(0.2392 \%)$. The treatment M4 also Recorded a significant in giving the highest average of this trait $(0.4561 \%)$ compared to other treatments, especially $\mathrm{M}_{2}$ and $\mathrm{M}_{3}$, where they gave (0.3706 and 0.3922) \% respectively. While the treatment $\mathrm{M}_{1}$ gave the lowest $(0.3022 \%)$.

The binary interaction showed a significant effect, the combination $\left(\mathrm{V}_{1} \times \mathrm{O}_{3}\right)$ gave the highest average for this characteristic $0.5000 \%$, while the combination $\left(\mathrm{V}_{2} \times \mathrm{O}_{1}\right)$ gave the lowest one $0.2200 \%$. Also, combination of $\left(\mathrm{V}_{1} \times \mathrm{M}_{4}\right)$ gave the highest average $0.4733 \%$, while the combination $\left(\mathrm{V}_{2} \times \mathrm{M}_{1}\right)$ gave the lowest average $0.2733 \%$. The interaction between two types of fertilizer had a significant effect, as the combination $\left(\mathrm{O}_{3} \times \mathrm{M}_{2}\right)$ gave a highest average $0.5367 \%$ compared to combination of $\left(\mathrm{O}_{1} \times \mathrm{M}_{1}\right)$ which gave the lowest rate $0.1550 \%$ (Table 4).

The triple interaction treatment among cultivars, organic and mineral fertilization achieved the highest rate in this trait. Thus, combination $\left(\mathrm{V}_{1} \times \mathrm{O}_{3} \times \mathrm{M}_{2}\right)$ gave the highest average $0.5467 \%$, while combination $\left(\mathrm{V}_{2} \times \mathrm{O}_{1} \times \mathrm{M}_{1}\right)$ gave the lowest mean of this trait $0.1300 \%$. 
TABLE(4): EFFECT OF CULTIVAR, ORGANIC AND MINERAL FERTILIZATION AND THEIR INTERACTIONS ON THE PERCENTAGE OF PHOSPHOROUS IN THE LEAVES (\%)

\begin{tabular}{|l|c|c|c|c|c|c|}
\hline \multirow{2}{*}{ Variety (V) } & Organic fertilization & \multicolumn{4}{|c|}{ Mineral fertilization (M) } & \multirow{2}{*}{ V*O } \\
\cline { 3 - 6 } & $(O)$ & $M_{1}$ & $M_{2}$ & $M_{3}$ & \\
\hline
\end{tabular}

\begin{tabular}{|c|c|c|c|c|c|c|}
\hline \multirow{3}{*}{$\mathbf{V}_{1}$} & $\mathrm{O}_{1}$ & 0.1800 & 0.2533 & 0.2600 & 0.3400 & 0.2583 \\
\hline & $\mathrm{O}_{2}$ & 0.3933 & 0.4800 & 0.4433 & 0.5333 & 0.4625 \\
\hline & $\mathrm{O}_{3}$ & 0.4200 & 0.4867 & 0.5467 & 0.5467 & 0.5000 \\
\hline \multirow{3}{*}{$\mathbf{V}_{2}$} & $\mathrm{O}_{1}$ & 0.1300 & 0.2133 & 0.2200 & 0.3167 & 0.2200 \\
\hline & $\mathrm{O}_{2}$ & 0.3333 & 0.4200 & 0.4500 & 0.4733 & 0.4192 \\
\hline & $\mathrm{O}_{3}$ & 0.3567 & 0.3700 & 0.4333 & 0.5267 & 0.4217 \\
\hline L.S.D ${ }_{0.05}$ & \multicolumn{5}{|c|}{$\mathbf{V} \times \mathbf{O} \times \mathbf{M}=0.02925$} & $\mathbf{V} * \mathbf{O}=0.01486$ \\
\hline \multirow{3}{*}{$\mathbf{V} \times \mathbf{M}$} & & & & & & Mean (V) \\
\hline & $\mathrm{V}_{1}$ & 0.3311 & 0.4067 & 0.4167 & 0.4733 & 0.4069 \\
\hline & $\mathrm{V}_{2}$ & 0.2733 & 0.3344 & 0.3678 & 0.4389 & 0.3536 \\
\hline L.S.D 0.05 & \multicolumn{5}{|c|}{$\mathbf{V} \times \mathbf{M}=0.01694$} & $\mathbf{V}=0.01643$ \\
\hline & & & & & & Mean (O) \\
\hline \multirow{3}{*}{$\mathbf{O} \times \mathbf{M}$} & $\mathrm{O}_{1}$ & 0.1550 & 0.2333 & 0.2400 & 0.3283 & 0.2392 \\
\hline & $\mathrm{O}_{2}$ & 0.3633 & 0.4500 & 0.4467 & 0.5033 & 0.4408 \\
\hline & $\mathrm{O}_{3}$ & 0.3883 & 0.4283 & 0.4900 & 0.5367 & 0.4608 \\
\hline \multicolumn{2}{|c|}{ Mean (M) } & 0.3022 & 0.3706 & 0.3922 & 0.4561 & \\
\hline L.S.D 0.05 & $\mathbf{O} \times \mathbf{M}=0.02086$ & \multicolumn{4}{|c|}{$\mathbf{M}=0.01204$} & $\mathbf{O}=0.01043$ \\
\hline
\end{tabular}

Varieties $\left(\mathrm{V}_{1}=\right.$ Datis, $\mathrm{V}_{2}=$ Sakata); Organic fertilizer $\left(\mathrm{O}_{1}=\right.$ comparison, $\mathrm{O}_{2}=$ beef manure, $\mathrm{O}_{3}=$ poultry manure $)$; Mineral fertilizer (NPK) $\left(\mathrm{M}_{1}=0, \mathrm{M}_{2}=2.250, \mathrm{M}_{3}=3.350, \mathrm{M}_{4}=4.450\right) \mathrm{kg}$. dunam ${ }^{-1}$.

\section{E. The percentage of total carbohydrates in the fruits}

The results showed a significant variance of $\mathrm{V}_{1}$ cultivar than $\mathrm{V}_{2}$ cultivar, and their averages were (1.2876 and 1.2555$) \%$ respectively. The results indicated that treatment of organic fertilizer $\mathrm{O}_{3}$ was significantly superior in giving the highest average of $(1.3561 \%)$ in this characteristic compared to other treatments. And the treatment $\mathrm{O}_{2}$ significantly reached $(1.2292 \%)$ compared to the control treatment $\left(\mathrm{O}_{1}\right)$ that recorded the lowest average $(1.166)$ The reason for this may be due to the role of organic matter, especially poultry waste, in increasing ability of the root to grow and absorb ready-made elements, especially the potassium element, which has an important role in stimulating the process of photosynthesis and transfer of its products by stimulating the formation of ATP, which is needed to fill (phloem tissue). On the other hand, the effect of mineral fertilizer significantly affected this trait; thus, the treatment $\mathrm{M}_{3}$ recorded the highest mean of carbohydrate in fruits $(1.293 \%)$, which significantly differed compared to other treatment. The treatment $\mathrm{M}_{1}$ gave the lowest average, reaching $(1.2343 \%)$.

The results showed a significant effect of bilateral interaction, the combination $\left(V_{1} \times M_{2}\right)$ gave the highest average for this characteristic $1.3091 \%$, while combination $\left(\mathrm{V}_{2} \times \mathrm{M}_{1}\right)$ gave the lowest $1.2042 \%$. The combination $\left(\mathrm{O}_{3} \times \mathrm{M}_{3}\right)$ gave a highest 
average $1.3795 \%$ compared to $\left(\mathrm{O}_{1} \times \mathrm{M}_{1}\right)$, which gave the lowest $1.1085 \%$. The triple interaction treatment among study factors achieved the highest average in this trait; thus, combination $\left(\mathrm{V}_{1} \times \mathrm{O}_{3} \times \mathrm{M}_{3}\right)$ gave the highest average of $1.4047 \%$, whereas the combination $\left(\mathrm{V}_{2} \times \mathrm{O}_{1} \times \mathrm{M}_{1}\right)$ gave the lowest $1.0427 \%$.

TABLE(5) : EFFECT OF CULTIVAR, ORGANIC AND MINERAL FERTILIZATION AND THEIR INTERACTIONS ON THE PERCENTAGE OF TOTAL CARBOHYDRATES IN THE FRUITS (\%)

\begin{tabular}{|c|c|c|c|c|c|c|}
\hline \multirow{2}{*}{ Variety (V) } & \multirow{2}{*}{$\begin{array}{c}\text { Organic } \\
\text { fertilization }(O)\end{array}$} & \multicolumn{4}{|c|}{ Mineral fertilization (M) } & \multirow{2}{*}{$\mathbf{V}^{*} \mathbf{O}$} \\
\hline & & $\mathbf{M}_{1}$ & $\mathbf{M}_{2}$ & $\mathbf{M}_{3}$ & $\mathbf{M}_{4}$ & \\
\hline \multirow{3}{*}{$\mathbf{V}_{1}$} & $\mathrm{O}_{1}$ & 1.1743 & 1.1763 & 1.1957 & 1.1957 & 1.1855 \\
\hline & $\mathrm{O}_{2}$ & 1.2883 & 1.3017 & 1.3270 & 1.3043 & 1.3053 \\
\hline & $\mathrm{O}_{3}$ & 1.3307 & 1.3580 & 1.4047 & 1.3940 & 1.3718 \\
\hline \multirow{3}{*}{$\mathbf{V}_{2}$} & $\mathrm{O}_{1}$ & 1.0427 & 1.1783 & 1.1830 & 1.1817 & 1.1464 \\
\hline & $\mathrm{O}_{2}$ & 1.2533 & 1.2823 & 1.2933 & 1.2900 & 1.2798 \\
\hline & $\mathrm{O}_{3}$ & 1.3167 & 1.3283 & 1.3543 & 1.3620 & 1.3403 \\
\hline L.S.D 0.05 & \multicolumn{5}{|c|}{$\mathbf{V} \times \mathbf{O} \times \mathbf{M}=0.02885$} & $\mathbf{V}^{*} \mathbf{O}=\mathrm{N} . \mathrm{S}$ \\
\hline \multirow{3}{*}{$\mathbf{V} \times \mathbf{M}$} & & & & & & Mean (V) \\
\hline & $\mathrm{V}_{1}$ & 1.2644 & 1.2787 & 1.3091 & 1.2980 & 1.2876 \\
\hline & $\mathrm{V}_{2}$ & 1.2042 & 1.2630 & 1.2769 & 1.2770 & 1.2555 \\
\hline L.S.D 0.05 & \multicolumn{5}{|c|}{$\mathbf{V} \times \mathbf{M}=0.01637$} & $\mathbf{V}=0.01469$ \\
\hline & & & & & & Mean (O) \\
\hline \multirow{3}{*}{$\mathbf{O} \times \mathbf{M}$} & $\mathrm{O}_{1}$ & 1.1085 & 1.773 & 1.1893 & 1.1887 & 1.1660 \\
\hline & $\mathrm{O}_{2}$ & 1.2708 & 1.2920 & 1.3102 & 1.2972 & 1.2925 \\
\hline & $\mathrm{O}_{3}$ & 1.3237 & 1.3432 & 1.3795 & 1.3780 & 1.3561 \\
\hline \multicolumn{2}{|c|}{ Mean (M) } & 1.2343 & 1.2708 & 1.2930 & 1.2879 & \\
\hline L.S.D 0.05 & $\mathbf{O} \times \mathbf{M}=0.02072$ & \multicolumn{4}{|c|}{$\mathbf{M}=0.1196$} & $\mathbf{O}=0.01036$ \\
\hline
\end{tabular}

Varieties $\left(\mathrm{V}_{1}=\right.$ Datis, $\mathrm{V}_{2}=$ Sakata); Organic fertilizer $\left(\mathrm{O}_{1}=\right.$ comparison, $\mathrm{O}_{2}=$ beef manure, $\mathrm{O}_{3}=$ poultry manure); Mineral fertilizer (NPK) $\left(\mathrm{M}_{1}=0, \mathrm{M}_{2}=2.250, \mathrm{M}_{3}=3.350, \mathrm{M}_{4}=4.450\right) \mathrm{kg}$. dunam ${ }^{-1}$.

\section{F. Yield per plant $\left(\mathrm{kg}\right.$. plant $\left.^{-1}\right)$}

From the results (Table. 6), the significant effect among the experiment factors was recorded in this trait; thus cultivar $\mathrm{V}_{1}$ appeared high effect on the yield compared to other cultivar and achieved a $1.402 \mathrm{~kg}$ plant-1 of fruit yield to $1.145 \mathrm{~kg}$ plant $^{-1}$ that achieved by cultivar $\mathrm{V}_{2}$. On the other hand, the same effect was recorded for the mineral fertilizer treatments in the yield; thus, both treatments $\mathrm{M}_{2}$ and $\mathrm{M}_{4}$ recorded the highest yield (1.682 and $1.420 \mathrm{~kg}$ plant ${ }^{-1}$ ) respectively, which they were significantly exceeded both other treatments $M_{3}$ and $M 1$ that they reached (1.080 and $\left.0.913 \mathrm{~kg}^{\mathrm{plant}}{ }^{-1}\right)$ respectively. The interaction between two types of fertilizers had a significant effect in yield per plant thus, combinations $\left(\mathrm{O}_{1} \times \mathrm{M}_{2}\right),\left(\mathrm{O}_{3} \times \mathrm{M}_{2}\right)$ and $\left(\mathrm{O}_{2} \times \mathrm{M}_{4}\right)$ gave the highest average in this trait $(2.337,1.842$ and $1.911 \mathrm{~kg}$. plant-1) respectively, compared with a combination $\left(\mathrm{O}_{1} \times \mathrm{M}_{1}\right)$, which gave the lowest at $0.792 \mathrm{~kg}$. plant ${ }^{-1}$. 
TABLE(6): EFFECT OF CULTIVAR, ORGANIC AND MINERAL FERTILIZATION AND THEIR INTERACTIONS ON YIELD PER PLANT (KG. PLANT ${ }^{-1}$ )

\begin{tabular}{|c|c|c|c|c|c|c|}
\hline & Organic & \multicolumn{4}{|c|}{ Mineral fertilization (M) } & \multirow[b]{2}{*}{$\bar{V} \mathbf{V} * \mathbf{O}$} \\
\hline Variety (V) & $\begin{array}{c}\text { fertilization } \\
\text { (O) }\end{array}$ & $\mathbf{M}_{1}$ & $\mathbf{M}_{2}$ & $\mathbf{M}_{3}$ & $\mathbf{M}_{4}$ & \\
\hline & $\mathrm{O}_{1}$ & 0.798 & 2.976 & 1.204 & 1.278 & 1.564 \\
\hline $\mathbf{V}_{1}$ & $\mathrm{O}_{2}$ & 1.158 & 0.768 & 1.140 & 1.860 & 1.231 \\
\hline & $\mathrm{O}_{3}$ & 0.936 & 2.280 & 0.882 & 1.548 & 1.411 \\
\hline & $\mathrm{O}_{1}$ & 0.786 & 1.699 & 0.804 & 0.918 & 1.052 \\
\hline $\mathbf{V}_{2}$ & $\mathrm{O}_{2}$ & 0.895 & 0.828 & 1.620 & 1.824 & 1.292 \\
\hline & $\mathrm{O}_{3}$ & 0.905 & 1.542 & 0.829 & 1.092 & 1.092 \\
\hline L.S.D 0.05 & \multicolumn{5}{|c|}{$\mathbf{V} \times \mathbf{O} \times \mathbf{M}=\mathrm{N} . \mathrm{S}$} & $\mathbf{V} * \mathbf{O}=\mathrm{N} . \mathrm{S}$ \\
\hline & & & & & & Mean (V) \\
\hline \multirow[t]{2}{*}{$\mathbf{V} \times \mathbf{M}$} & $\mathrm{V}_{1}$ & 0.964 & 2.008 & 1.075 & 1.562 & 1.402 \\
\hline & $\mathrm{V}_{2}$ & 0.862 & 1.356 & 1.084 & 1.278 & 1.145 \\
\hline \multirow[t]{3}{*}{ L.S.D 0.05} & \multicolumn{5}{|c|}{$\mathbf{V} \times \mathbf{M}=\mathrm{N} . \mathrm{S}$} & $\mathbf{V}=0.1437$ \\
\hline & & & & & & Mean (O) \\
\hline & $\mathrm{O}_{1}$ & 0.792 & $2 . .337$ & 1.004 & 1.089 & 1.308 \\
\hline \multirow[t]{2}{*}{$\mathbf{O} \times \mathbf{M}$} & $\mathrm{O}_{2}$ & 1.026 & 0.798 & 1.380 & 1.842 & 1.262 \\
\hline & $\mathrm{O}_{3}$ & 0.920 & 1.911 & 0.855 & 1.320 & 1.252 \\
\hline \multicolumn{2}{|c|}{ Mean (M) } & 0.913 & 1.682 & 1.080 & 1.420 & \\
\hline L.S.D 0.05 & $\mathbf{O} \times \mathbf{M}=0.8165$ & \multicolumn{4}{|c|}{$\mathbf{M}=0.4714$} & $\mathbf{O}=\mathrm{N} . \mathrm{S}$ \\
\hline
\end{tabular}

Varieties $\left(\mathrm{V}_{1}=\right.$ Datis, $\mathrm{V}_{2}=$ Sakata $)$; Organic fertilizer $\left(\mathrm{O}_{1}=\right.$ comparison, $\mathrm{O}_{2}=$ beef manure, $\mathrm{O}_{3}=$ poultry manure $)$; Mineral fertilizer (NPK) $\left(\mathrm{M}_{1}=0, \mathrm{M}_{2}=2.250, \mathrm{M}_{3}=3.350, \mathrm{M}_{4}=4.450\right) \mathrm{kg}$. dunam ${ }^{-1}$.

\section{DISCUSSION}

The results showed the significant effect of the experimental factors and their interactions on the traits under this study described in the results section. To understand these significant influences among the study factors, we looked to the reasons for the behavior of these factors; thus, the cultivars Datis and Sakata showed differences response on the traits, and this might be due to the nature of genetic factors (Sudre Et al., 2010) specific to variety Datis $\left(\mathrm{V}_{1}\right)$ in which determine the degree of its growth and development, which is represented by the increase in plant height and number of leaves (data is not available) compared to Sakata cultivar $\left(\mathrm{V}_{2}\right)$. The cultivar $\mathrm{V}_{1}$ significantly responded to the experiment environment compared to the cultivar $\mathrm{V}_{1}$, which was cleared on the fruits yield, percentage of nitrogen and phosphorous in leaves, and 
carbohydrates(Mahdi, 2016). This result was consistent with what found by by (Mahmoud and Al-Rawi, 2015; AlJubouri et al, 2017).

On the other hand, the results appeared the significant effect to the treatments of organic fertilizer 3.713 tons $\left(\mathrm{O}_{3}\right)$ compared to other treatments on all the trails except the yield of plant and the reasons might be due to an increase in the role of Organic matter which used as improves soil properties by improving ability of soil to hold water. Also, its important role in increasing nutrients, especially nitrogen, has a major role in increasing the effectiveness of carbon representation and building carbohydrates. The addition of organic fertilizers (animal waste), especially poultry manure, leads to a decrease $(\mathrm{pH})$ in the soil and increases the readiness of nutrients and to the production of hormones, including auxins and gibberellins, which work to encourage vegetative growth and this is reflected in outcome(Al-Sahhaf, 1994) .

As well as, the importance of adding poultry waste, it contains almost twice amount of nitrogen present in beef waste, in addition to containing large quantities of potassium and phosphorous. This leads to poultry manure's superiority in increasing percentage of nitrogen in plant leaves due increase in soil content of organic matter, ammonium and nitrates. and the increase in release nitrogen from them due to the mineralization process compared to manure from cattle manure. Al-Zobaie, (2000) and Al-Zahawi (2007)concluded that organic fertilizers led to secure nutrients in the soil and increase average of nitrogen and organic matter. Also, the role of organic matter, especially poultry waste, in increasing ability of the root to grow and absorb ready-made elements, especially the potassium element, which has an important role in stimulating the process of photosynthesis and transfer of its products by stimulating the formation of ATP, which is needed to fill phloem tissue(Viro, 1974).

The treatment $4.450 \mathrm{~kg}\left(\mathrm{M}_{4}\right)$ of mineral fertilizer showed the highest effect on most of this study's traits. The reasons for this may be is that addition of chemical fertilizer to the soil increased readiness of these nutrients in soil solution, which may lead to an increase in their absorption from the plant and a reflection of this information of an efficient root group in the absorption of nutrients from the soil (Tisdale et al. 1997). Also, raising yield is increase in concentration of these elements, which led to encouragement of the photosynthesis process and then manufactured of carbohydrates in leaves, their transfer and storage in fruits, which contributed to increase weight of fruit, which was positively reflected in the increase in total productivity of greenhouse, these results are in line with(Abd al-Rahman, 2013).The variation in percentage of nitrogen in the plant may be due to difference in content of added fertilizer (chemical and organic) of major and minor elements.

The high content of leaves in these elements may be attributed to potassium inactivation of many enzymes within the plant, which has an important role in the construction processes. As well as, the role of potassium in the transfer of carbohydrates manufactured in the plant from places of their manufacture to places of growth, which is reflected in the increase in growth of root hairs and thus increase efficiency of plants to absorb phosphorous and trace elements, transfer to leaves and increase their concentration in them. So, the role of Phosphorous in cell division and participation in plant life processes, including photosynthesis, increases the synthesis of carbohydrates resulting from photosynthesis . The effect of organic and chemical fertilizers added and its positive role in improving the physical and chemical properties of soil and equipping plant with necessary elements, especially nitrogen and potassium, which lead to an increase in the 
strength of vegetative growth and its activity, which is positively reflected in the increase Quotient and productivity. Also, it works to raise temperature of soil (Al-Ajeel, 1998). Therefore, this leads to provision of ideal conditions of growth of roots and an increase in activity of microorganisms and their preparation, which increased the readiness of nutrients and increased their absorption by plant, especially the elements necessary for plant growth. This affects strength of vegetative growth and then increases yield.

\section{Conclusion}

- Datis cultivar significantly outperformed in yield per plant, total yield, leaf content of nitrogen and phosphorus, and carbohydrates' fruit content.

- On the other hand, the treatment of organic fertilizer $\mathrm{O}_{3}$ recorded a significant effect in leaf area, total yield, leaf content of nitrogen and phosphorus, and fruit content of carbohydrate.

- The treatment $\mathrm{M}_{2}$ significantly outperformed in yield per plant, treatment $\mathrm{M}_{3}$ significantly exceeded the fruit's carbohydrate content, and $\mathrm{M}_{4}$ outperformed in leaf area, percentage of Nitrogen and Phosphorous in the leaves, and percentage of total carbohydrates in the fruits. 


\section{References}

1- Abd al-Rahman, H. B., Ghassan, J. Z., and Qutaybah, Y. A.( 2013). The effect of spraying with nutrient solutions on the quantitative and qualitative yield of two cucumber hybrids (Cucumis sativus L.) Diyala Journal of Agricultural Sciences 5 (2): 122-132.

2- Al-Ajil, S. A. (1998). The effect of salinity, organic residues and foliar nutrition on tomato plants in the Najaf region, $\mathrm{PhD}$ thesis, College of Agriculture, University of Baghdad.

3- Ali, N. S.( 2007). Introduction to soil fertility and fertilizer management. Baghdad University. Ministry of Higher Education and Scientific Research. Iraq.

4- Al-Jubouri, K. D., Hassan, H. M., Faleh, H. S. (2017). Effect of biological fertilizers and genotypes on growth and production of cucumber (Cucumis sativus L.). Anbar Journal of Agricultural Sciences, 15 (private issue). 308--317.

5- Al-Naimi, S. A.( 1987). Organic fertilizers and soil fertility. Ministry of Higher Education and Scientific Research. University of Al Mosul. Iraq.

6- Al-Sahhaf, F. H.( 1994). The effect of the number of times spraying with liquid nutrient solution (Al-Nahrain) on the growth and yield of potato Estima Journal of Iraqi Agricultural Sciences. Vol 25. Issue (1).

7- Al-Zahawi, S. M.( 2007). Effect of different organic fertilizers and soil cover on growth, yield and quality of potatoes. Master Thesis. Department of horticulture. College of Agriculture - University of Baghdad.

8- Duke, J. (1997). The Green Pharmacy. St. Martin’s Press, New York. pp:508.

9- Genstat .(2007). Seventh Edition (DE3) Servic Pack, Version, 7.2.0220, Lawes Agiculture alatrust.

10- Mahdi, S. S.( 2016). Study the genetic diversity of different types of Capsicum annuum L. for samples from local markets using some molecular genetic techniques. PhD thesis - College of Education for Pure Sciences - Ibn Al Haytham - University of Baghdad.

11- Mahmoud, H. A., and Marwan, A. T.( 2015). The effect of variety and planting dates on yield and components of cucumber plants (Cucumis sativus L.) in unheated greenhouses. Tikrit Journal of Agricultural Sciences 15 (1): 82-91.

12- Sahuki, M., Karima, M.W.( 1990). Applications in design and analysis of experiments. Baghdad University.

13- Sudre, C. P., , L. S. A. Gonçalves, , R. Rodrigues, A. T. Amaral Junior, E. M. Riva-Souza, and C. D. S. Bento .(2010). Genetic variability in domesticated Capsicum spp. as assessed by morphological and agronomic data in mixed statistical analysis. Genet. Mol. Res. 9 (1): 283-294.

14- Tisdal, S.L. ; Nelson, W.L. ; Beaton, J.D. and Harlin, J.L.( 1997). Soil fertility and fertilization Prentica Hall of India . New Delhi .

15- Vimala, P., C.C. Ting, H. Salbiah, B. Ibrahim and L. Ismail .(1999). Biomass reduction and nutrient yields of four green manures and their effects on the yield of Cucumber. Journal of Tropical Agric. and Food Science 27:4755

Page 12 